\title{
The independence of enzyme heterozygosity and life-history traits in natural populations of Salvelinus fontinalis (brook trout)
}

\author{
JEFFREY A. HUTCHINGS \& MOIRA M. FERGUSON \\ Institute of Cell, Animal and Population Biology, University of Edinburgh, Edinburgh, Scotland and Department of \\ Zoology, University of Guelph, Guelph, Ontario, Canada N1G 2W1
}

\begin{abstract}
The relationship was examined between allozyme heterozygosity at six polymorphic loci and several life-history traits (age and size at maturity, egg size, fecundity, proportional allocation of body tissue to gonads) within five natural, unexploited populations of brook trout (Salvelinus fontinalis) on Cape Race, Newfoundland, Canada. We tested two predictions of the hypothesis that increased allozyme heterozygosity enhances fitness. We found little or no support for the predictions that single or multilocus heterozygosity is (i) positively associated with the phenotypic value of life-history traits, and is (ii) negatively associated with trait variances. Neither single nor multilocus heterozygosity was positively associated with a life-history trait in 67 within-population analyses. Trait variance decreased significantly with increased multilocus heterozygosity in only 1 of 25 cases. We conclude that trade-offs, non-directional selection, relatively high environmental variation in life-history traits, and conflicting selection pressures on the same trait (in different stages of life) may combine to reduce the likelihood of detecting significant correlations between heterozygosity and those traits most closely related to fitness in natural populations.
\end{abstract}

Keywords: developmental homeostasis, fitness, heterozygosity, life-history, Salvelinus fontinalis.

\section{Introduction}

Heterozygous advantage has been hypothesized to be the primary mechanism by which natural selection maintains genetic variation in natural populations (Dobzhansky, 1955; reviewed by Lewontin, 1974). Positive associations between heterozygosity and rates of juvenile growth (Mitton \& Grant, 1984; Allendorf \& Leary, 1986; Zouros \& Mallet, 1989) and development (Mitton \& Grant, 1984; Danzmann et al., 1989) have been interpreted as evidence that heterozygosity enhances fitness. However, the relative influence of juvenile growth and development on fitness per se is considerably less than that of life-history traits such as offspring size and number, allocation of body tissue to reproductive tissue, and age and size at reproduction. Life-history traits directly influence age-specific rates of survival and fecundity, the most important components of $r$, the intrinsic rate of natural increase, and the definition of fitness used by most evolutionary and population biologists (Charlesworth, 1980, 1990).

Correspondence: J. A. Hutchings, Institute of Cell, Animal and Population Biology, University of Edinburgh, West Mains Road, Edinburgh EH9 3JT, Scotland.
Mitton \& Grant (1984) recommended that associations between heterozygosity and life-history traits be measured to evaluate the hypothesis that increased heterozygosity enhances fitness. Positive associations between heterozygosity and life-history traits have been documented. Schaal \& Levin (1976) reported a positive correlation between heterozygosity and ovule number in the herb, Liatris cylindracea. Cone production is similarly associated with heterozygosity in the ponderosa pine, Pinus ponderosa, (Linhart et al., 1979). Heterozygous individuals have been reported to be more fecund than homozygotes in blue mussels, Mytilus edulis, (Rodhouse et al., 1986) and in brook trout, Salvelinus fontinalis, (Liskauskas \& Ferguson, 1990). Danzmann et al. (1988) documented a positive correlation between heterozygosity and egg size in rainbow trout, Oncorhynchus mykiss, although a similar association was absent in a study of brook trout (Liskauskas \& Ferguson, 1990). However, with the exception of the pine studied by Linhart et al. (1979), none of the studies which have documented positive associations between heterozygosity and life-history traits have been conducted on natural, unexploited populations. 
One fitness advantage attributed to heterozygosity is an increased capacity to be buffered against environmental perturbations of development (Lerner, 1954). If developmental homeostasis is positively associated with heterozygosity, then the variance in fitness-related traits should decrease as heterozygosity increases (Mitton \& Grant, 1984). Support for this prediction has been documented for scale and fin morphology in killifish, Fundulus heteroclitus, (Mitton, 1978) and for wing characteristics in the monarch butterfly, Danaus plexippus, (Eanes, 1978) although such correlations have not been measured for life-history traits.

We examined the relationship between heterozygosity and life-history traits in natural, unperturbed populations of brook trout on Cape Race, southeastern Newfoundland, Canada. Life-history variation within and among populations is reflected by differences in size and age at maturity, egg size, fecundity, and the allocation of body tissue to gonads (Hutchings, 1990). Allozyme variation at six of 42 enzyme-coding loci examined has also been documented within and among these populations (Ferguson et al., 1991). Our objective was to test the predictions, based upon the hypothesis of heterozygous advantage, that enzyme heterozygosity is positively associated with the phenotypic value and negatively associated with the variance of life-history traits.

\section{Materials and methods}

Brook trout were electrofished from five rivers on Cape Race (an area of $120 \mathrm{~km}^{2}$ bounded by $53^{\circ} 16^{\prime} \mathrm{W}$, $46^{\circ} 45^{\prime} \mathrm{N}, 53^{\circ} 04^{\prime} \mathrm{E}$, and $46^{\circ} 38^{\prime} \mathrm{S}$ ). These wholly freshwater populations inhabited Drook, Freshwater, Watern Cove, Cripple Cove, and Cape Race rivers (see Hutchings, 1990, for stream characteristics). Collections were made 7-10 days prior to reproduction (i.e. early October). All individuals were frozen at $-20^{\circ} \mathrm{C}$ shortly after capture.

Several life-history traits were measured for mature males and females. Fork length (measured to the nearest $1 \mathrm{~mm}$ ) and body weight (to the nearest $0.01 \mathrm{~g}$ ) at maturity were recorded for each individual. Age at maturity was assessed by scale examination. Female gonads were weighed to the nearest $0.01 \mathrm{~g}$ and expressed as a proportion of body weight by the gonadosomatic index (GSI = gonad weight/total body weight). Fecundity was measured as the absolute number of eggs in each female. Egg size was calculated to be the mean diameter (measured to the nearest 0.01 $\mathrm{mm}$, using vernier calipers) of 10 eggs chosen at random from each female.

Genetic variation was quantified with an electrophoretic analysis of 42 enzyme-coding loci (Leary \&
Booke, 1990). The products of six loci were polymorphic within and among populations (Ferguson et al., 1991). These enzymes, specific loci and their respective alleles were alcohol dehydrogenase $(\mathrm{ADH}$ : $-29,-100)$, glycerol-3-phosphate dehydrogenase (G3P-1: 100, 167), isocitrate dehydrogenase (IDH-4: $65,80,100)$, lactate dehydrogenase (LDH-3: 72, 100), malic enzyme (ME-1: 0, 50, 100), and phosphoglucomutase (PGM-1: $\phi, 100)$. The Cripple Cove population showed no variation at $I D H-4, L D H-3$, and $P G M-1$. Cape Race fish were monomorphic at $I D H-4$. With one exception, individuals were coded as being either homozygous or heterozygous at each locus. Phenotypes at $P G M-1$ were coded as being either active $(100 / \phi, 100 / 100)$ or inactive $(\phi / \phi)$ because of the difficulty in distinguishing between individuals with $(100 / \phi)$ and $(100 / 100)$ genotypes.

Associations between enzyme heterozygosity and life-history traits were examined in two ways. Multilocus heterozygosity was measured as the number of heterozygous loci per individual. Associations between multilocus heterozygosity and life-history traits (females: age and weight at maturity, fecundity, egg size, GSI; males: age and weight at maturity) were assessed by rank correlation using Kendall's coefficient $(\tau)$ because multilocus heterozygosity was not distributed normally. This approach assumes that the effects of each locus on each trait are equal and additive (Liskauskas \& Ferguson, 1990).

The second approach allowed for the possibility that the effects of individual loci are unequal and not additive. Individual loci were coded either 0 (homozygote) or 1 (heterozygote). Loci that had fewer than five homozygous or heterozygous individuals were excluded from the analysis (this criterion excluded Drook). These class variables were incorporated into a multiple regression analysis as independent variables. The dependent variables and their respective independent body size variables (in parentheses) were fecundity (weight), egg size (weight), and GSI (length). The multiplicative effects of individual loci on body weight were evaluated separately for males and females. The 25 regression models (five populations, five dependent variables) were determined with a stepwise regression analysis (Draper \& Smith, 1981) (significance levels for entry and exit tests were $\alpha=0.05$ and $\alpha=0.10$, respectively, as recommended by Sokal \& Rohlf, 1981). Homoscedasticity of the trait variances among individuals with different numbers of heterozygous loci were assessed with either the $F$ test (two samples) or the $F_{\max }$ test (more than two samples).

The results yielded several tables of test statistics $(\tau$, $F$, and $\left.F_{\max }\right)$. The statistical significance of component tests within tables was assessed by simultaneous infer- 
ence to control for the observation that the probability of rejecting one or more true null hypotheses (Type-I error) increases with the number of tests in a group (Rice, 1989). As recommended and described by Rice (1989), we used the sequential Bonferroni technique to control the group-wide Type-I error rate and to simultaneously maintain power in detecting one or more false null hypotheses (Type-II error) in each table. Thus, to be significant at the table-wide $\alpha$ level of 0.05 , the smallest $P$-value in the table must have been less than $\alpha / k$, where $k$ is the number of simultaneous tests in the table. If the test statistic with the smallest $P$-value was judged to be significant, then the second smallest $P$ must have been less than $\alpha / k-1$ to be significant. These comparisons continued until the inequality $P_{i} \leq \alpha /(1+k-i)$ was not met.

\section{Results}

Multilocus heterozygosity was uncorrelated with male and female age and size at maturity, fecundity, egg size and GSI within the five populations (Table 1). (The lack of association between age and multilocus heterozygosity allowed the data to be pooled across ages for the remaining analyses.) Single locus heterozygosity accounted for significant but small amounts of variation in two of the 25 multiple regression models (Table 2). For Freshwater females, $L D H-3$ accounted for 11 and 13 per cent (partial $R^{2}$ values) of the variation in GSI and in weight at maturity, respectively. The negative partial regression coefficients for $L D H-3$ reflected negative effects of heterozygosity at this locus on GSI and female weight at maturity in the Freshwater population.

The variance in life-history traits differed significantly among individuals with different numbers of heterozygous loci in two of the 25 tests of homoscedasticity (Table 3; $F_{\max }$ tests, $P<0.001$ for both populations). Variation in weight among Freshwater males with one heterozygous locus was significantly greater than those with two heterozygous loci $\left(F=8.98 ; P_{[16,24]}<0.0001\right)$. However, individuals that had two heterozygous loci had significantly lower variation in weight than did individuals with three heterozygous loci $\left(F=3.88 ; P_{[19,24]}=0.0011\right)$. In the Cape Race population, homozygosity was associated with increased variation in male weight (e.g. comparing homozygous males with those with two heterozygous loci, $\left.F=45.89 ; P_{[5,7]}<0.0001\right)$.

\section{Discussion}

The present study found little support for the predictions that heterozygosity is (i) positively associated with the phenotypic values of life-history traits, and (ii) negatively associated with trait variances. Multilocus heterozygosity was uncorrelated with a life-history trait in all 42 within-population analyses. Heterozygosity at individual loci accounted for significant variation in a life-history trait in only two of 25 cases examined and the partial regression coefficients for these cases were negative, contrary to theoretical predictions. Trait variance was generally independent of heterozygosity ( 23 of 25 cases). Of the 92 analyses performed herein, the predicted relationships between heterozygosity and the phenotypic value/variance of life-history traits were affirmed in only one case (trait variance in weight at maturity for Cape Race males decreased with increasing heterozygosity).

The lack of significantly positive associations between life-history traits and both single and multilocus heterozygosity in brook trout is not surprising and, for many organisms, it may be unreasonable to expect such associations to exist a priori. Under the assumption that selection favours increased heterozygosity, the prediction that heterozygosity should be positively associated with life-history traits assumes implicitly that directional selection acts on those traits. An abundance of evidence, however, indicates that negative phenotypic and genetic correlations exist between life-history traits and that these trade-offs often result in balancing rather than directional selection on each trait (Charlesworth, 1980, 1990; Stearns, 1989). Thus, for traits that are most strongly related to fitness, high levels of heterozygosity may be more closely associated with intermediate rather than extreme (high or low) values of such traits, although small-scale, environmentally induced, temporal changes in selection intensities (Schluter et al., 1991) may make it difficult to detect such associations in wild populations.

The positive associations that have been documented between life-history traits and heterozygosity in some studies and the absence of such associations in others (e.g. Christiansen \& Frydenberg, 1976; Allendorf \& Leary, 1986; Zouros et al., 1988; Liskauskas \& Ferguson, 1990; Whitehurst \& Pierce, 1991) may reflect interspecific variation in the strength of genetic correlations among life-history traits. Most of the positive correlations for fecundity have been found in organisms in which variation in offspring size, above a physiological minimum, confers no variation in offspring fitness. That is, in environments in which survival is largely random with respect to offspring size, an individual's evolutionarily stable strategy is to maximize offspring number and to disperse the offspring as widely as possible (Brockelman, 1975). Thus, for a broadcast spawner such as the blue mussel or for wind- 
Table 1 Kendall's coefficient of rank correlation between multilocus heterozygosity and five life-history traits in mature brook trout from five populations on Cape Race, Newfoundland

\begin{tabular}{|c|c|c|c|c|c|c|c|}
\hline Population & Sex & $n$ & $\begin{array}{l}\text { Age at } \\
\text { maturity }\end{array}$ & $\begin{array}{l}\text { Weight at } \\
\text { maturity }\end{array}$ & Fecundity & $\begin{array}{l}\text { Egg } \\
\text { size }\end{array}$ & GSI \\
\hline \multirow[t]{2}{*}{ Freshwater } & $\mathrm{F}$ & 68 & $\begin{array}{l}-0.09 \\
(0.411)\end{array}$ & $\begin{array}{c}-0.18 \\
(0.050)\end{array}$ & $\begin{array}{c}-0.12 \\
(0.198)\end{array}$ & $\begin{array}{c}-0.13 \\
(0.162)\end{array}$ & $\begin{array}{c}-0.04 \\
(0.668)\end{array}$ \\
\hline & $\mathbf{M}$ & 72 & $\begin{array}{l}0.34 \\
(0.739)\end{array}$ & $\begin{array}{l}0.03 \\
(0.711)\end{array}$ & & & \\
\hline \multirow[t]{2}{*}{ Drook } & $F$ & 11 & $\begin{array}{c}-0.24 \\
(0.376)\end{array}$ & $\begin{array}{c}-0.19 \\
(0.446)\end{array}$ & $\begin{array}{c}-0.02 \\
(0.933)\end{array}$ & $\begin{array}{l}-0.50 \\
(0.052)\end{array}$ & $\begin{array}{c}-0.54 \\
(0.034)\end{array}$ \\
\hline & $\mathbf{M}$ & 11 & $\begin{array}{l}0.26 \\
(0.356)\end{array}$ & $\begin{array}{l}0.23 \\
(0.367)\end{array}$ & & & \\
\hline \multirow[t]{2}{*}{$\begin{array}{c}\text { Cripple Cove } \\
1987\end{array}$} & $\mathrm{~F}$ & 20 & $\begin{array}{c}0.09 \\
(0.687)\end{array}$ & $\begin{array}{l}0.06 \\
(0.748)\end{array}$ & $\begin{array}{c}-0.01 \\
(0.972)\end{array}$ & $\begin{array}{l}0.12 \\
(0.498)\end{array}$ & $\begin{array}{c}-0.31 \\
(0.087)\end{array}$ \\
\hline & $\mathbf{M}$ & 30 & $\begin{array}{c}0.06 \\
(0.720)\end{array}$ & $\begin{array}{c}-0.01 \\
(0.967)\end{array}$ & & & \\
\hline \multirow[t]{2}{*}{$\begin{array}{l}\text { Cripple Cove } \\
1988\end{array}$} & $\mathrm{~F}$ & 24 & $\begin{array}{c}-0.31 \\
(0.099)\end{array}$ & $\begin{array}{c}-0.17 \\
(0.327)\end{array}$ & $\begin{array}{c}-0.18 \\
(0.298)\end{array}$ & $\begin{array}{l}0.11 \\
(0.513)\end{array}$ & $\begin{array}{c}-0.25 \\
(0.130)\end{array}$ \\
\hline & $\mathbf{M}$ & 28 & $\begin{array}{c}0.24 \\
(0.155)\end{array}$ & $\begin{array}{c}0.28 \\
(0.084)\end{array}$ & & & \\
\hline \multirow[t]{2}{*}{ Cape Race } & $\mathbf{F}$ & 31 & $\begin{array}{c}-0.01 \\
(0.982)\end{array}$ & $\begin{array}{l}0.13 \\
(0.376)\end{array}$ & $\begin{array}{l}0.11 \\
(0.463)\end{array}$ & $\begin{array}{l}-0.16 \\
(0.256)\end{array}$ & $\begin{array}{c}-0.06 \\
(0.658)\end{array}$ \\
\hline & $\mathbf{M}$ & 33 & $\begin{array}{c}-0.16 \\
(0.313)\end{array}$ & $\begin{array}{c}-0.21 \\
(0.128)\end{array}$ & & & \\
\hline \multirow[t]{2}{*}{ Watern Cove } & $\mathrm{F}$ & 24 & $\begin{array}{c}-0.11 \\
(0.550)\end{array}$ & $\begin{array}{c}-0.08 \\
(0.590)\end{array}$ & $\begin{array}{l}0.13 \\
(0.425)\end{array}$ & $\begin{array}{c}-0.08 \\
(0.607)\end{array}$ & $\begin{array}{l}0.09 \\
(0.555)\end{array}$ \\
\hline & $\mathbf{M}$ & 20 & $\begin{array}{c}0.46 \\
(0.018)\end{array}$ & $\begin{array}{c}0.53 \\
(0.003)\end{array}$ & & & \\
\hline
\end{tabular}

$\mathrm{GSI}=$ gonad weight/total body weight.

$(P$ values in parentheses; all $P$ values exceeded the table-wide significance level of $0.05 ; \alpha / k=0.05 / 42=0.001)$.

dispersing plants, increased fecundity directly increases fitness (subject to any costs of reproduction sensu Williams, 1966). If heterozygosity enhances fitness, then fecundity should be positively correlated with heterozygosity in such species (e.g. Schaal \& Levin, 1976; Linhart et al., 1979; Rodhouse et al., 1986). Positive associations between heterozygosity and fecundity in brook trout (Liskauskas \& Ferguson, 1990) and egg size in rainbow trout (Danzmann et al., 1988) are unexpected given the trade-off that typically exists between egg size and egg number in salmonids (Fleming \& Gross, 1990; Hutchings, 1991). Maternal fitness in salmonid fish is clearly a function of the number and of the size of eggs produced by each female (Smith \& Fretwell, 1974; Winkler \& Wallin, 1987; Hutchings, 1991). Thus, assuming that natural selection in the wild approximates weak balancing selection (Endler, 1986), for a given allocation of body tissue to gonads, increasing either fecundity or egg size beyond their optimal values should reduce fitness and result in non-significant linear associations between these traits and heterozygosity. The positive associations between heterozygosity and brook trout fecundity and rainbow trout egg size may reflect the fact that the salmonids in these studies were presently or recently (i.e. within four generations) exposed to directional selection for increased body size (with concomitant correlational selection on egg size and fecundity) in hatchery environments.

The independence of heterozygosity and body size among Cape Race brook trout is not unexpected given that all fish were sexually mature (Ferguson, 1990; Liskauskas \& Ferguson, 1991). Declines in growth rate of larger and more heterozygous fish during maturation can account for the age-dependent weakening of the relationship between multilocus heterozygosity and 
Table 2 Loci with $P$ values less than 0.05 in multiple regression analyses of lifehistory traits in mature brook trout from five populations on Cape Race

\begin{tabular}{|c|c|c|c|c|c|c|c|}
\hline \multirow[b]{2}{*}{ Population } & \multirow[b]{2}{*}{ Sex } & \multirow{2}{*}{$\begin{array}{l}\text { Dependent } \\
\text { variable }\end{array}$} & \multirow{2}{*}{$\begin{array}{l}\text { Independent } \\
\text { variable }\end{array}$} & \multirow[b]{2}{*}{$\beta$} & \multicolumn{3}{|c|}{ Partial } \\
\hline & & & & & $R^{2}$ & $F$ & $P$ \\
\hline \multirow[t]{5}{*}{ Freshwater } & $\mathrm{F}$ & Egg size & Weight & 0.03 & 0.47 & 57.94 & $0.001 *$ \\
\hline & & & IDH-4 & -0.15 & 0.03 & 4.04 & 0.049 \\
\hline & & GSI & LDH-3 & -0.03 & 0.11 & 7.93 & $0.006^{*}$ \\
\hline & & & $\mathrm{ADH}$ & 0.02 & 0.07 & 5.17 & 0.030 \\
\hline & & Weight & LDH-3 & -5.80 & 0.13 & 9.83 & $0.003^{*}$ \\
\hline Cripple Cove $\dagger$ & $\mathrm{F}$ & Weight & G3P-1 & 9.00 & 0.34 & 9.17 & 0.007 \\
\hline \multirow[t]{3}{*}{ Watern Cove } & $\mathrm{F}$ & Fecundity & Weight & 1.64 & 0.45 & 18.66 & $0.001 *$ \\
\hline & & & ME-1 & 15.94 & 0.12 & 6.07 & 0.020 \\
\hline & M & Weight & G3P-1 & 16.73 & 0.26 & 6.24 & 0.022 \\
\hline \multirow[t]{2}{*}{ Cape Race } & $F$ & Fecundity & Weight & 1.06 & 0.20 & 7.21 & 0.012 \\
\hline & & & PGM-1 & 8.34 & 0.11 & 4.45 & 0.040 \\
\hline
\end{tabular}

*Significance at the table-wide $\alpha$ level of $0.05 ; k=60$ for male and female weights (five populations $\times$ two dependent variables $x$ six independent variables) and $k=105$ for GSI, fecundity and egg size (five populations $\times$ three dependent variables $\times$ seven independent variables); $\uparrow 1987$ sample.

( $\beta=$ partial regression coefficient $)$.

Table 3 Statistically significant relationships (at table-wide $\alpha$ level of $0.05 ; \alpha / k=0.05 / 25=0.002$ ) between variance in life-history traits and heterozygosity in mature brook trout from populations on Cape Race

\begin{tabular}{|c|c|c|c|c|c|}
\hline Population & Sex & Trait & $n$ & $\begin{array}{l}\text { Number of } \\
\text { heterozygous } \\
\text { loci }\end{array}$ & $\begin{array}{l}\text { Trait } \\
\text { variance }\end{array}$ \\
\hline \multirow[t]{4}{*}{ Freshwater } & $\mathbf{M}$ & Weight & 17 & 1 & 109.41 \\
\hline & & & 25 & 2 & 12.18 \\
\hline & & & 20 & 3 & 47.20 \\
\hline & & & 5 & 4 & 33.29 \\
\hline \multirow[t]{3}{*}{ Cape Race } & $\mathbf{M}$ & Weight & 6 & 0 & 1417.88 \\
\hline & & & 15 & 1 & 31.36 \\
\hline & & & 8 & 2 & 30.90 \\
\hline
\end{tabular}

body size observed in many salmonids (Ferguson, 1990, 1992). A positive correlation between heterozygosity and growth rate early in life, and the absence of such an association later in life, reflects differential selection pressures on growth rate at different stages of life.

The present study suggests that heterozygosity has little influence on the developmental homeostasis of life-history traits. Although in accordance with the findings of Booth et al. (1990), this result contrasts with several studies which have documented significantly positive associations between multilocus hetero- zygosity and developmental stability [e.g. scale and fin ray characteristics in killifish (Mitton, 1978); forewing characteristics in monarch butterflies (Eanes, 1978); fluctuating asymmetry of scale morphometry in lizards (Soule, 1979) and of meristic characters in several salmonids (Leary et al., 1984)]. It may be significant that positive results have been documented for morphological traits, characters that are often highly heritable (Mousseau \& Roff, 1987) and relatively uninfluenced by the environment. In contrast, life-history traits have relatively low heritability (Mousseau \& Roff, 1987) and can be strongly influenced by the environment (Partridge \& Harvey, 1988). Thus, associations between developmental homeostasis and heterozygosity may be more likely to be detected, and of increasing selective importance, as the additive genetic and environmental variances associated with a trait increase and decrease, respectively.

The primary assumption of any investigation which examines the relationship between heterozygosity and fitness-related traits is that the phenotypic variation of the traits of interest is due directly to the enzyme loci examined or is due to a steady-state linkage disequilibrium between the measured loci and the loci directly responsible for the phenotypic effects, i.e. associative overdominance (Zouros, 1987; Zouros et al., 1988). We have no evidence that the loci considered here directly influence life-history traits in brook trout. Under associative overdominance, the detection of heterozygosity/fitness correlations depends on the 
strength of the genetic correlations between the scored enzyme loci and those they are marking. Houle (1989) has argued that species which show such correlations have population structures or histories which tend to promote genotypic correlations between scored loci and loci segregating for deleterious recessive alleles. Such correlations can be produced by gametic phase disequilibrium between marked loci and deleterious genes or by inbreeding. It is possible that processes which promote homozygous excess, thus amplifying the effects of associative overdominance (Zouros \& Mallet, 1989), are absent in the Cape Race populations but this cannot be reliably assessed without information on effective population size and genetic correlations between loci.

In conclusion, associations between heterozygosity and life-history may be uncommon in natural populations (cf. Zouros \& Foltz, 1987). Environmental variation is likely to mask any effects that heterozygosity might have on the phenotype and developmental stability of life-history traits. Trade-offs, non-directional selection and conflicting selection pressures on the same trait in different stages of life (references in Schluter et al., 1991) may further reduce the probability of detecting positive correlations between heterozygosity and those traits most closely related to fitness in natural populations.

\section{Acknowledgements}

JAH was supported by a Natural Sciences and Engineering Research Council (NSERC) Postgraduate Scholarship, a NSERC Postdoctoral Fellowship, a Sigma Xi Grant-In-Aid of Research, an Atlantic Salmon Foundation Olin Fellowship, and a NSERC Operating Grant to Douglas W. Morris. The electrophoretic analysis was supported by a NSERC Operating Grant to MMF and by an Environmental Youth Corp award (Ontario Ministry of Natural Resources) to Roy Danzmann. We thank Mariane Piche for her technical assistance with the electrophoresis. David Innes and two anonymous reviewers provided helpful comments on an earlier version of the manuscript.

\section{References}

ALLENDORF, F. W. AND LEARY, R. F. 1986. Heterozygosity and fitness in natural populations of animals. In: Soule, M. E. (ed.) Conservation Biology, Sinauer, Sunderland, MA, pp. 57-76.

BOOTH, C. L., WOODRUFF, D. S. AND GOULD, s. J. 1990. Lack of significant correlations between allozyme heterozygosity and phenotypic traits in the land snail Cerion. Evolution, 44, 210-213.

BROCKELMAN, W. Y. 1975. Competition, fitness of offspring, and optimal clutch size. Am. Nat., 109, 677-699.

CHARlesworth, B. 1980. Evolution In Age-Structured Populations. Cambridge University Press, Cambridge.

CHARLESWORTH, B. 1990. Optimization models, quantitative genetics, and mutation. Evolution, 44, 520-538.

CHRISTIANSEN, F. B. AND FRYDENBERG, o. 1976. Selection component analysis of natural polymorphisms using mother-offspring samples of successive cohorts. In: Karlin, S. and Nevo, E. (eds) Population Genetics and Ecology, Academic Press, New York, pp. 277-301.

DANZMANN, R. G., FERGUSON, M. M. AND ALLENDORF, F. W. 1988. Heterozygosity and components of fitness in rainbow trout. Biol. J. Linn. Soc., 33, 285-304.

DANZMANN, R. G., FERGUSON, M. M. AND ALLENDORF, F. W. 1989. Genetic variability and components of fitness in a strain of rainbow trout, J. Fish Biol., 35, (Suppl. A) 313-319.

DOBZHANSKY, Th. 1955. A review of some fundamental concepts and problems of population genetics. Cold Spring Harbor Group Symp. Quant. Biol., 20, 1-15.

DRAPER, N. R. AND SMITH, H. 1981. Applied Regression Analysis. John Wiley \& Sons, New York.

EANES, W. F. 1978. Morphological variance and enzyme heterozygosity in the monarch butterfly. Nature, 276, 263-264.

ENDlER, J. A. 1986. Natural Selection In The Wild. Princeton University Press, Princeton.

FERGUSON, M. M. 1990. Heterozygosity and growth of rainbow trout reared at two rations. Biol. J. Linn. Soc., 40, 215-227.

FERGUSON, M. M. 1992. Enzyme heterozygosity and growth in rainbow trout: genetic and physiological explanations. Heredity, 68, 115-122.

FERGUSON, M. M., DANZMANN, R. G. AND HUTCHINGS, J. A. 1991. Incongruent estimates of population differentiation among brook charr from Cape Race, Newfoundland, Canada, based upon allozyme and mitochondrial DNA variation. $J$. Fish Biol., 39, (Suppl. A) 79-85.

FLEMING, I. A. AND GROSS, M. R. 1990. Latitudinal clines: a tradeoff between egg number and size in Pacific salmon. Ecology, 71, 1-11.

Houle, D. 1989. Allozyme-associated heterosis in Drosophila melanogaster. Genetics, 123, 789-801.

HUTCHINGS, J. A. 1990. The evolutionary significance of life history divergence among brook trout, Salvelinus fontinalis, populations. Ph.D. Thesis, Memorial University of Newfoundland.

HUTCHINGS, J. A. 1991. Fitness consequences of variation in egg size and food abundance in brook trout, Salvelinus fontinalis. Evolution, 45, 1162-1168.

LEARY, R. F., ALLENDORF, F. W. AND KNUDSEN, K. L. 1984. Superior developmental stability of heterozygotes at enzyme loci in salmonid fishes. Am. Nat., 124, 540-551.

LEARY, R. F. AND BOOKE, H. E. 1990. Starch gel electrophoresis and species distinctions. In: Schreck, C. B. and Moyle, P. B. (eds) Methods For Fish Biology, American Fisheries Society, Bethesda, pp. 141-170. 
LERNER, I. M. 1954. Genetic Homeostasis. Oliver and Boyd, Edinburgh.

LEWontin, R. C. 1974. The Genetic Basis of Evolutionary Change. Columbia University Press, New York.

LINHART, Y. B., MITTON, J. B., BOWMAN, D. M., STURGEON, K. B. AND HAMRICK, J. L. 1979. Genetic aspects of fertility differentials in ponderosa pine. Genet. Res., 33, 237-242.

LISKAUSKAS, A. P. AND FERGUSON, M. M. 1990. Enzyme heterozygosity and fecundity in a naturalized population of brook trout (Salvelinus fontinalis). Can. J. Fish. Aquat. Sci., 47, 2010-2015.

LISKAUSKAS, A. P. AND FERGUSON, M. M. 1991. Genetic variation and fitness: a test in a naturalized population of brook trout (Salvelinus fontinalis). Can. J. Fish. Aquat. Sci., 48, 2152-2162.

MITTON, J. в. 1978. Relationship between heterozygosity for enzyme loci and variation of morphological characters in natural populations. Nature, 273, 661-662.

MITTON, J. B. AND GRANT, M. C. 1984. Associations among protein heterozygosity, growth rate, and developmental homeostasis. Ann. Rev. Ecol. Syst., 15, 479-499.

MOUSSEAU, T. A. AND ROFF, D. A. 1987. Natural selection and the heritability of fitness components. Heredity, 59, 181-197.

PARTRIDGE, L. AND HARVEY, P. 1988. The ecological context of life-history evolution. Science, 241, 1449-1455.

RICE, W. R. 1989. Analyzing tables of statistical tests. Evolution, 43, 223-225.

RODHOUSE, P. G., MCDONALD, J. H., NEWELL, R. I. E. AND KOEHN, R. K. 1986. Gamete production, somatic growth and multiplelocus enzyme heterozygosity in Mytilus edulis. Mar. Biol., 90, 209-214.

SCHAAL, B. A. AND LEVIN, D. A. 1976. The demographic genetics of Liatris cylindracea Michx. Am. Nat., 110, 191-206.

SCHLUTER, D., PRICE, T. D. AND ROWE, L. 1991. Conflicting selection pressures and life history trade-offs. Proc. R. Soc. Lond. B, 246, 11-17.

SMTTH, C. C. AND FRETWELL, S. D. 1974. The optimal balance between size and number of offspring. Am. Nat., 108, 499-506.

SOKAL, R. R. AND ROHLF, F. J. 1981. Biometry. Freeman, San Francisco.

SOULE, M. E. 1979. Heterozygosity and developmental stability: another look. Evolution, 33, 396-401.

STEARNS, s. C. 1989. Trade-offs in life-history evolution. Funct. Ecol., 3, 259-268.

WHITEHURST, P. H. AND PIERCE, B. A. 1991. The relationship between allozyme variation and life-history traits of the spotted chorus frog, Pseudacris clarkii. Copeia, 1991, 1032-1039.

WILlIAMS, G. C. 1966 . Natural selection, the cost of reproduction, and a refinement of Lack's principle. Am. Nat., 100, 687-690.

WINKLER, D. W. AND WALLIN, K. 1987. Offspring size and number: a life history model linking effort per offspring and total effort. Am. Nat., 129, 708-720.

zouRos, E. w. 1987 . On the relation between heterozygosity and heterosis: an evaluation of the evidence from marine mollusks. In: Rattazzi, M. C., Scandalios, J. G. and Whitt, G. S. (eds) Isozymes: Current Topics in Biological and Medical Research, vol. 15, A. R. Liss, New York, pp. 255-270.

zouRos, E. W. AND FoLTZ, D. 1987. The use of allelic isozyme variation for the study of heterosis. In: Rattazzi, M. C., Scandalios, J. G. and Whitt, G. S. (eds) Isozymes: Current Topics in Biological and Medical Research, vol. 13, A. R. Liss, New York, pp. 1-59.

zouRos, E. W. AND MALLET, A. L. 1989. Genetic explanations of the growth/heterozygosity correlation in marine mollusks. In: Ryland, J. S. and Tyler, P. A. (eds) Reproduction, Genetics and Distributions of Marine Organisms, Olsen \& Olsen, Fredensborg, pp. 317-324.

ZOUROS, E. W., ROMERO-DOREY, M. AND MALLET, A. L. 1988. Heterozygosity and growth in marine bivalves: further data and possible explanations. Evolution, 42, 13321341. 